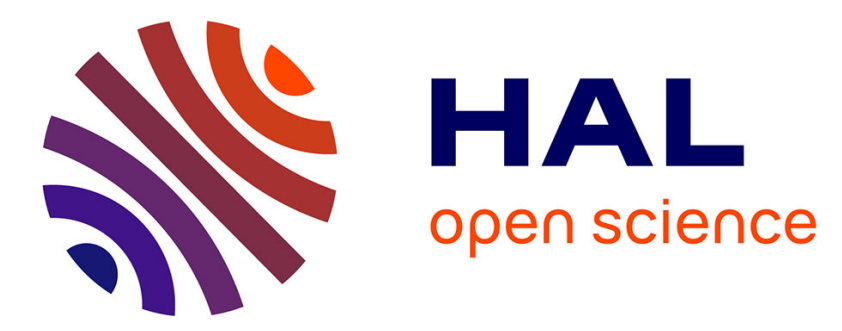

\title{
Oxygen isotopes and ecological inferences of Permian (Guadalupian) tetrapods from the main Karoo Basin of South Africa
}

Kévin Rey, Michael Day, Romain Amiot, François Fourel, Julie Luyt, Marc van den Brandt, Christophe Lécuyer, Bruce Rubidge

\section{To cite this version:}

Kévin Rey, Michael Day, Romain Amiot, François Fourel, Julie Luyt, et al.. Oxygen isotopes and ecological inferences of Permian (Guadalupian) tetrapods from the main Karoo Basin of South Africa. Palaeogeography, Palaeoclimatology, Palaeoecology, 2020, 538, pp.109485. 10.1016/j.palaeo.2019.109485 . hal-02991787

\section{HAL Id: hal-02991787 \\ https://hal.science/hal-02991787}

Submitted on 17 Nov 2020

HAL is a multi-disciplinary open access archive for the deposit and dissemination of scientific research documents, whether they are published or not. The documents may come from teaching and research institutions in France or abroad, or from public or private research centers.
L'archive ouverte pluridisciplinaire HAL, est destinée au dépôt et à la diffusion de documents scientifiques de niveau recherche, publiés ou non, émanant des établissements d'enseignement et de recherche français ou étrangers, des laboratoires publics ou privés. 


\section{Journal Pre-proof}

Oxygen isotopes and ecological inferences of Permian (Guadalupian) tetrapods from the main Karoo Basin of South Africa

Kévin Rey, Michael O. Day, Romain Amiot, François Fourel, Julie Luyt, Marc J. Van den Brandt, Christophe Lécuyer, Bruce S. Rubidge

PII: $\quad$ S0031-0182(19)30845-4

DOI: $\quad$ https://doi.org/10.1016/j.palaeo.2019.109485

Reference: $\quad$ PALAEO 109485

To appear in: $\quad$ Palaeogeography, Palaeoclimatology, Palaeoecology

Received date: $\quad 19$ September 2019

Revised date: $\quad 21$ November 2019

Accepted date: $\quad 21$ November 2019

Please cite this article as: K. Rey, M.O. Day, R. Amiot, et al., Oxygen isotopes and ecological inferences of Permian (Guadalupian) tetrapods from the main Karoo Basin of South Africa, Palaeogeography, Palaeoclimatology, Palaeoecology (2018), https://doi.org/10.1016/j.palaeo.2019.109485

This is a PDF file of an article that has undergone enhancements after acceptance, such as the addition of a cover page and metadata, and formatting for readability, but it is not yet the definitive version of record. This version will undergo additional copyediting, typesetting and review before it is published in its final form, but we are providing this version to give early visibility of the article. Please note that, during the production process, errors may be discovered which could affect the content, and all legal disclaimers that apply to the journal pertain.

C) 2018 Published by Elsevier. 
Oxygen isotopes and ecological inferences of Permian (Guadalupian) tetrapods from the main Karoo Basin of South Africa

Kévin Rey ${ }^{1, *}$, Michael O. Day ${ }^{1,2}$, Romain Amiot ${ }^{3}$, François Fourel ${ }^{4}$, Julie Luyt ${ }^{5}$, Marc J. Van den Brandt ${ }^{1}$, Christophe Lécuyer ${ }^{3, a}$, Bruce S. Rubidge ${ }^{1}$.

${ }^{1}$ Evolutionary Studies Institute and the School of Geosciences, University of the Witwatersrand, P.O. WITS 2050, Johannesburg, South Africa.

${ }^{2}$ Department of Earth Sciences, Natural History Museum, Cromwell Road, London SW7 5BD, United Kingdom

${ }^{3}$ Univ Lyon, Université Lyon 1, ENS de Lyon, CNRS, UMR 5276 LGL-TPE, F-69622,

Villeurbanne, France, 2, Rue Raphaël Dubois, 69622 Villeurbanne Cedex, France.

${ }^{4}$ Univ Lyon, Université Lyon 1, CNRS, UMR 5023 LEHNA, F-69622, Villeurbanne, France,

3, Rue Raphaël Dubois, 69622 Villeurbanne Cedex, France.

${ }^{5}$ Department of Archaeology, University of Cape Town, Private Bag X3, Rondebosch, 7701, South Africa.

${ }^{a}$ Also at Institut Universitaire de France.

* Corresponding author: Evolutionary Studies Institute and the School of Geosciences, University of the Witwatersrand, P.O. WITS 2050, Johannesburg, South Africa. E-mail address: kevin.rey@ wits.ac.za (K. Rey). 


\section{Abstract}

The Abrahamskraal Formation of South Africa has a diverse middle Permian (Guadalupian) fossil tetrapod fauna comprising largely basal therapsids and pareiasaurian parareptiles. Knowledge on the paleoecology of these animals is limited because inferences of many ecological traits in mid-Permian tetrapods are based on deductions from morphology. While it is widely accepted that the rhinesuchid amphibians were aquatic, the ecological lifestyle of pareiasaurs and dinocephalian therapsids remains uncertain. To investigate the ecological roles of different middle Permian tetrapod taxa we studied stable oxygen isotope compositions of phosphate from teeth and bones as a proxy for water dependence. Our results reveal similar $\delta^{18} \mathrm{O}_{\mathrm{p}}$ values for pareiasaurs, the dinocephalian Anteosaurus, and therocephalians, with a range of values similar to those of extant terrestrial species. The consistent $\delta^{18} \mathrm{O}_{\mathrm{p}}$ values for pareiasaurs strengthen our interpretation of a terrestrial lifestyle for these parareptiles, but the lower Anteosaurus $\delta^{18} \mathrm{O}_{\mathrm{p}}$ values might question the interpretation and a larger sample size may result in a more conclusive outcome. These results conclude the debate on the ecology of middle Permian pareiasaurs. A terrestrial lifestyle is applicable only to the middle Permian species and a different lifestyle is possible for pareiasaurs species that lived after the end Capitanian extinction.

Keywords: Anteosaurus; pareiasaur; Paleoecology; Phosphate apatite; Abrahamskraal Formation 


\section{Introduction}

The rich tetrapod fauna from the Abrahamskraal Formation of South Africa provides a unique window onto high latitude fauna of Gondwana during the middle Permian (Guadalupian). One of its major constituent taxa, dinocephalian therapsids, achieved widespread distribution across Pangaea (Cisneros et al., 2012; Liu, 2013; Golubev, 2015); other well-represented groups, including dicynodont therapsids, rhinesuchid temnospondyls and pareiasaurian parareptiles, were restricted to Gondwana at this time (Golubev, 2005; Fröbisch, 2009; Kurkin, 2011). The fauna is best known from the Capitanian-aged Tapinocephalus Assemblage Zone from the upper Abrahamskraal Formation, which is terminated by the extinction of $75-80 \%$ of tetrapod species, including all dinocephalians at a global scale and all Guadalupian pareiasaur species at a local scale (Day et al., 2015).

The causes of the Capitanian mass extinction event are unclear with several hypotheses proposed such as the Emeishan volcanism (Zhou et al., 2002; Wignall et al., 2009; Bond and Wignall, 2014), marine anoxia (Jin et al., 1994; Hallam and Wignall, 1999; Isozaki et al., 2008; Saitoh et al., 2013), global marine regression or even the release of methane in the atmosphere (Krull et al., 2000; Krull and Retallack, 2000; Retallack and Jahren, 2008; Svensen et al., 2009). Although most of these causes have been either questioned (Bond et al., 2010; Sheldon et al., 2014) or might not have had impact on the continental fauna and flora (Sheldon et al., 2014), with the possible exception of the volcanism in South China (Day et al., 2015), conditions in the southwestern Karoo Basin may have been exacerbated by regional aridification resulting from tectonic activity to the south (Rey et al., 2018). Clues to the causes, as well as to the question of how ecosystems react to different forms of disruption, can be found in the ecological characters of individual species and their place within food webs. While the lifestyle and ecological niche occupation of some species can be inferred 
from morphological characters (Canoville and Laurin, 2010; Canoville and Chinsamy, 2015; Jasinoski et al., 2009), this is not true for all tetrapods. Incompletely preserved skeletons lacking key parts of the anatomy, the presence of characters that are not known in extant tetrapods, or discrepancies between ecological deductions from morphology and other disciplines can all lead to uncertainty (Canoville and Chinsamy, 2017).

The pareiasaurs and dinocephalians that succumbed to the Capitanian mass extinction appear to differ in a few ecological characters: they have very disparate dentition, suggesting that the herbivores consumed different types of vegetation, and their skeletons are usually preserved under different taphonomic conditions (Boonstra, 1969), suggesting different lifestyles. The lifestyle of pareiasaurs in particular has been variously interpreted, when not inconclusive (Canoville and Chinsamy, 2017; Boitsova et al., 2019), as completely aquatic (Case, 1926; Ivakhnenko, 2001), amphibious (Boonstra, 1969; Ochev, 2004; Khlyupin, 2007; Kriloff et al., 2008), or terrestrial (Voigt et al., 2010; Benton et al., 2012; Canoville et al., 2014; Verrière et al., 2016). Similarly, the dinocephalian Anteosaurus, while generally accepted to have been a fully terrestrial animal (Nicolas and Rubidge, 2010; Kammerer, 2011; Kemp, 2012; Canoville et al., 2014), has also been considered to have been riparian (Boonstra, 1955, 1962), or even amphibious (Ivakhnenko, 2008).

Stable isotopic studies of hard tissues are useful to determine certain lifestyle aspects of animals. For instance, this technique can be used to reconstruct the relationship of an individual to aquatic environments. Stable oxygen isotope composition $\left(\delta^{18} \mathrm{O}\right)$ of vertebrate apatite is correlated to both body temperature and to the oxygen isotope composition of body water $\left(\delta^{18} \mathrm{O}_{\mathrm{bw}}\right)$, which is mostly derived from the consumption of either meteoric water or plant water, or a combination of both (D’Angela and Longinelli, 1990; Kohn, 1996). Once 
ingested this water undergoes fractionation, mostly caused by transcutaneous evaporation, urine and faeces (Luz and Kolodny, 1985; Bryant and Froelich, 1995; Amiot et al., 2007). Fractionation, which increases ${ }^{18} \mathrm{O}$ in the remaining body water, is therefore more intense for species which do not replenish their body water by drinking often (Cerling et al., 2008) and less intense when transcutaneous evaporation is reduced as a result of an aquatic or semiaquatic lifestyle (Clementz et al., 2008; Amiot et al., 2010). Consequently, for extant mammals, species which consume large quantities of water, or spend much time in water, have lower $\delta^{18} \mathrm{O}_{\mathrm{bw}}$ values than those with a strict terrestrial ecology and only consume plants (Bocherens et al., 1996; Kohn et al., 1996; Cerling et al., 2008). For example, two studies dedicated to the isotopic analysis of mammals from national parks in Kenya have shown that the $\delta^{18} \mathrm{O}$ values recorded in the apatite of extant hippopotamus are lower than those of coexisting terrestrial mammals such as lions, elephants and even waterbuck. Depending on the water-dependence of the terrestrial species (i.e. obligate drinkers or not), the $\delta^{18} \mathrm{O}$ values of the hippopotamus are about 3\%o lower than those of water-dependent animals and the difference can be as high as 7\%o when compared with water-independent species (Bocherens et al., 1996; Cerling et al., 2008; Fig. 1; Table 1). The $\delta^{18} \mathrm{O}$ values of the semi-aquatic hippopotamus, when compared with the $\delta^{18} \mathrm{O}$ values of ingested water, fit between the equations for terrestrial placental mammals (Amiot et al., 2004), those for crocodilians (Amiot et al., 2007) and freshwater turtles (modified from Bocherens et al., 1996; Fig. 1). A more complete review of $\delta^{18} \mathrm{O}$ values for hippopotamus and co-existing vertebrates has been compiled from extant and fossil individuals (Clementz et al., 2008) showing constant lower values for the semi-aquatic hippopotamus. Accordingly, by comparing the apatite $\delta^{18} \mathrm{O}$ values of various co-existing vertebrates of contrasting lifestyles, it should be possible to interpret the ecology of extinct taxa as has been done by Amiot et al. (2010) for spinosaurid dinosaurs. 
In an earlier study Canoville et al. (2014), while undertaking research on the ecology of pareiasaurs, pointed out that most of the dinocephalians had lower oxygen isotope compositions than the rest of the tetrapod sample; however, they still interpreted dinocephalians to be fully terrestrial based on the standard deviation of their values. Rey et al. (2016) also concluded that the Guadalupian pareiasaurs were fully terrestrial, but their conclusions were only tentative as their study was undertaken on a small sample size derived from specimens curated in different museum collections in South Africa. To clarify this point, and to strengthen our comparisons, we have increased our sample size of dinocephalians, pareiasaurs and other taxa, and measured the carbon and oxygen isotope compositions of apatite carbonate as well as the phosphate oxygen isotope compositions of both bones and teeth.

\section{Material and methods}

\subsection{Sample collection}

A feature of this isotope study, apart from being the most taxonomically extensive yet undertaken in the Abrahamskraal Formation, is that the tetrapod fossils sampled are well provenanced and come from a number of different lithostratigraphic members in stratigraphic succession. This is the first time that such a stratigraphically controlled isotope study has been undertaken in the Abrahamskraal Formation, but has the disadvantage that for some of the stratigraphic members only a few specimens of particular taxa were found. Bone apatite of twenty-six tetrapod fossils were sampled, and for seventeen of them teeth were also sampled. All samples were analysed for their stable oxygen isotope composition of apatite phosphate and carbonate. The fossils were recovered from eight localities within a radius of $100 \mathrm{~km}$ in the Main Karoo Basin, between $21.0^{\circ}$ and $22.1^{\circ}$ of latitude and -32.9 and $-32.2^{\circ}$ of longitude 
(Fig. 2; Supplementary Table 1), and are curated in the collection of the Evolutionary Studies Institute, University of the Witwatersrand, Johannesburg. Most specimens were collected by the authors of this study and are characterized by a secure taxonomic identification.

All sampled fossils were collected from horizons belonging to the Abrahamskraal Formation, which is subdivided into eight members respectively named from the lowest to the highest: Combrinkskraal, an unnamed member, Grootfontein, Leeuvlei, Koornplaats, Swaerskraal, Moordenaars and Karelskraal members (Day et al., 2018). To compensate as much as possible for temporal variations in isotopic values, we combined the localities from stratigraphically equivalent horizons (Supplementary Table 1) which were divided into three time bins. The lowest (one locality) corresponds to the upper Leeuvlei Member, the middle bin combines four localities from the lower to lower-middle Moordenaars Member and one between the upper Koornplaats and lower Moordenaars members, and the uppermost bin combines two localities from the overlying Karelskraal Member.

Sample sizes were severely limited by the availability of species from specific geological horizons and, due to the destructive and targeted nature of sampling for stable isotope analysis, the availability of suitable specimens with appropriate and reliable taxonomic data. The sample collection assembled for this study included one rhinesuchid amphibian, twelve therapsids, and thirteen pareiasaurs. The therapsid sample-set comprises ten dinocephalians - five Titanosuchidae indet., one tapinocephalid (Criocephalosaurus sp.), and four Anteosaurus magnificus — and two therocephalians (Glanosuchus sp. specimens). In South Africa, four pareiasaur species have been recognized from the middle Permian: Bradysaurus baini, B. seeleyi, Embrithosaurus schwarzi and Nochelesaurus alexanderi (Lee, 1997; Van den Brandt et al., 2019). As the pareiasaur specimens sampled are not all well 
preserved, only six could be reliably identified with three Bradysaurus bainii, two

Embrithosaurus schwarzi and one Nochelesaurus alexanderi; the remaining seven specimens cannot be identified to genus and are referable only to the family level (pers. com. M. Van den Brandt; see Supplementary Table 1).

Apart from the above specimens we collected, fossil data obtained from the De Bad locality were also included (Rey et al., 2016, 2017). This sample collection comprises six dinocephalians - two Criocephalosaurus, one addition tapinocephalid (either Mormosaurus or Struthiocephalus), one Titanosuchidae indet., two Anteosaurus - one therocephalian (Glanosuchus), and two pareiasaurs (one Bradysaurus baini and one unidentified).

To obviate biases resulting from environmental change over time, the stable isotope oxygen of phosphate apatite $\left(\delta^{18} \mathrm{O}_{\mathrm{p}}\right)$ and the stable isotope carbon of carbonate apatite $\left(\delta^{13} \mathrm{C}_{\mathrm{c}}\right)$ boxplots obtained per taxon were plotted against their respective stratigraphic members (Figs. 5 and 6).

\subsection{Analytical techniques}

The phosphate radical is of interest as the molecular bond is stronger than that of carbonate and inorganic alteration at low temperature has little effect on their $\delta^{18} \mathrm{O}_{\mathrm{p}}$ values (Lécuyer et al., 1999). Comparison between the phosphate and carbonate values allows us to potentially detect isotopic compositions of diagenetic origin (Iacumin et al., 1996). In order to measure the oxygen isotope composition of the apatite phosphate radicals, we isolated these ions using acid dissolution and anion-exchange resin applying a standard protocol (Lécuyer, 2004). Once quantitatively precipitated in a thermostatic bath set at a temperature of $70{ }^{\circ} \mathrm{C}$, the silver phosphate was filtered, washed with double deionized water, and dried at $50{ }^{\circ} \mathrm{C}$. 
Oxygen isotope compositions of the powders were measured using a high-temperature pyrolysis technique involving a VarioPYROcube ${ }^{\mathrm{TM}}$ elemental analyzer (EA) interfaced in continuous flow $(\mathrm{CF})$ mode to an Isoprime ${ }^{\mathrm{TM}}$ isotopic ratio mass spectrometer (IRMS) (EAPy-CF-IRMS technique) at the Laboratoire de Géologie de Lyon (UMR 5276, Université Claude Bernard Lyon 1). For each sample, five aliquots of $300 \mu \mathrm{g}$ of $\mathrm{Ag}_{3} \mathrm{PO}_{4}$ were mixed with $300 \mu \mathrm{g}$ of pure graphite powder and loaded in silver foil capsules.

Pyrolysis was performed at $1450{ }^{\circ} \mathrm{C}$. Measurements were calibrated against the NBS120c (natural Miocene phosphorite from Florida: $\delta^{18} \mathrm{O}=21.7 \%$; Lécuyer et al., 1993)) and the NBS127 (barium sulfate, $\mathrm{BaSO}_{4}: \delta^{18} \mathrm{O}=9.3 \%$; Hut, 1987). Silver phosphate samples precipitated from standard NBS120c were repeatedly analysed $\left(\delta^{18} \mathrm{O}_{\mathrm{p}}=21.7 \% ; 1 \sigma=0.3 ; \mathrm{n}=\right.$ 12) along with the silver phosphate samples derived from fossil bioapatites to ensure that no isotopic fractionation occurred during the wet chemistry. Data are reported as $\delta^{18} \mathrm{O}_{\mathrm{p}}$ values vs. V-SMOW (in \%o $\delta$ units).

About $10 \mathrm{mg}$ of tooth or bone powder was pre-treated (Koch et al., 1997) for measuring the oxygen isotope composition of the apatite carbonate. Powders were washed with a $2 \% \mathrm{NaOCl}$ solution to remove organic matter, then rinsed five times with double deionized water and air-dried at $40{ }^{\circ} \mathrm{C}$ for 24 hours. Potential secondary carbonate was removed by adding $0.1 \mathrm{M}$ acetic acid and leaving overnight, after which the powder was again rinsed five times with double deionized water and air-dried at $40{ }^{\circ} \mathrm{C}$ overnight. The powder/solution ratio was kept constant at $0.04 \mathrm{~g} \cdot \mathrm{mL}^{-1}$ for both treatments. The tubes were placed in a Thermo Finnigan Model II gas bench in a temperature controlled sampler tray set to $72^{\circ} \mathrm{C}$ (housed in the Stable Light Isotope Laboratory of the Archaeology Department of the University of Cape Town). For each sample, an aliquot of $2 \mathrm{mg}$ of pre-treated apatite was 
reacted with 7 drops of supersaturated orthophosphoric acid at $72{ }^{\circ} \mathrm{C}$ for at least two hours under a He atmosphere before starting 9 measurement cycles of the isotopic composition of the $\mathrm{CO}_{2}$ produced with a Thermo Finnigan Delta Plus XP continuous flow isotope ratio mass spectrometer. The measured carbon and oxygen isotopic compositions were calibrated relative to the NBS-18, NBS-19 and an internal calcite standard 'Cavendish Marble'. Reproducibility for the carbon and oxygen isotopic compositions of apatite carbonate is better than $\pm 0.15 \%$ o and $\pm 0.20 \%$, respectively. The carbon and oxygen isotopic compositions are expressed as $\delta$ values relative to $\mathrm{V}-\mathrm{PDB}$ for both carbon and oxygen (in \%o $\delta$ units). The oxygen values were converted from V-PDB to V-SMOW following the equation from Coplen et al. (1983).

\subsection{Robustness of the stable isotope record}

In contrast to the structure of extant mammal teeth, tooth enamel of Permian tetrapods is so thin that it was not possible to sample enough material suitable for isotopic analysis. Consequently, we focused our sampling on bone and tooth dentine; however, those bioapatites have more porous apatite than enamel, with smaller and less densely inter-grown crystals (Mills, 1967). Thus, secondary precipitation within or on the surface of bioapatite crystals, adsorption of ions on the surface of those crystals, or even dissolution and recrystallization along with isotopic exchange could have altered their original isotope composition. To differentiate apatites "isotopically-altered" by diagenesis from those partly altered or unaltered, all samples were tested for primary preservation by comparing their $\delta^{18} \mathrm{O}_{\mathrm{p}}$ values against their $\delta^{18} \mathrm{O}_{\mathrm{c}}$ values as recommended by Iacumin and Longinelli (1996).

In the skeletal tissue of extant mammals, the $\delta^{18} \mathrm{O}_{\mathrm{p}}$ and $\delta^{18} \mathrm{O}_{\mathrm{c}}$ are positively correlated because apatite precipitates close to equilibrium with water for both phosphate and carbonate components. As isotopic exchange rates between carbonate-water and phosphate-water are 
highly contrasted, re-equilibration of both compounds during diagenesis is not expected to be a common process and altered enamel should show isotopic shifts from the empirical $\delta^{18} \mathrm{O}_{\mathrm{p}}-$ $\delta^{18} \mathrm{O}_{\mathrm{c}}$ line (Iacumin et al., 1996). It is therefore expected that the distribution of pristine or weakly altered $\delta^{18} \mathrm{O}_{\mathrm{p}}$ and $\delta^{18} \mathrm{O}_{\mathrm{c}}$ values should display a positive regression line with a slope close to unity. At low temperature, inorganic alteration has little effect on the phosphate of the apatite, even at the scale of geological time (Tudge, 1960; Lécuyer et al., 1999), and would result in high overall carbonate content or a low discrepancies between carbonate $\delta^{18} \mathrm{O}_{\mathrm{c}}$ and phosphate $\delta^{18} \mathrm{O}_{\mathrm{p}}$ values. However, apatites can be mineralogically and isotopically altered during microbially-mediated diagenesis (Zazzo et al., 2004), which should be shown by greater $\delta^{18} \mathrm{O}_{\mathrm{c}}-\delta^{18} \mathrm{O}_{\mathrm{p}}$ differences. The carbonate content can be estimated from the mean magnitude of the current voltage $(\mathrm{mV})$ measured during the analysis of the $\mathrm{CO}_{2}$ by mass spectrometer (Supplementary Table 1).

\section{Results}

In our dataset, most of the samples analysed by mass spectrometry yielded peaks for the mass 44 with a mean magnitude of around $1000 \mathrm{mV}$ and $3000 \mathrm{mV}$, which is in accordance with the sample weights (Rey et al., 2018). However, two samples (1782-B and 7241-B) are characterized by mean magnitudes of $3900 \mathrm{mV}$ and $5600 \mathrm{mV}$ respectively, which are greater than the rest of the studied sample, hence suggesting an excess of carbonate in the apatite structure. Moreover, $\delta^{18} \mathrm{O}_{\mathrm{p}}$ and $\delta^{18} \mathrm{O}_{\mathrm{c}}$ values of these samples significantly deviate from the empirical regression line (Fig. 3). Therefore, we consider that those two samples lost their pristine isotopic compositions. The altered state of the sample 1782-B was also highlighted by comparing bone and tooth isotopic ratios from the same specimens. While both $\delta^{13} \mathrm{C}_{\mathrm{c}}$ and $\delta^{18} \mathrm{O}_{\mathrm{p}}$ values (Fig. 4A-C) are close to the empirical line, the $\delta^{18} \mathrm{O}_{c}$ value of bone sample 1782- 
B (Fig. 4B) is abnormally high compared to the tooth. Of the total of 43 samples, two are considered to have diagenetically altered $\delta^{18} \mathrm{O}_{\mathrm{c}}$ and $\delta^{13} \mathrm{C}_{\mathrm{c}}$ values.

Once the diagenetic and outlying values were removed from the dataset, the $\delta^{18} \mathrm{O}_{\mathrm{p}}$ and $\delta^{18} \mathrm{O}_{c}$ values of the remaining weakly or non-altered samples were identified to range between 4.1\%o and 7.7\%o V-SMOW, and between $10.7 \%$ and 15.1\%o V-SMOW, respectively. Nonaltered samples have $\delta^{13} \mathrm{C}_{\mathrm{c}}$ values that range from $-13.4 \%$ to $-6.4 \%$ V-PDB. These results show that the different species of pareiasaurs from neighbouring localities share similar $\delta^{18} \mathrm{O}_{\mathrm{p}}$ values. Consequently, for the purposes of this study we have not differentiated between the different pareiasaur genera.

\subsection{Oxygen isotopes}

For both the Moordenaars and Karelskraal Members, the $\delta^{18} \mathrm{O}_{\mathrm{p}}$ median values do not show significant differences compared to other $\delta^{18} \mathrm{O}_{\mathrm{p}}$ median values from the same horizon (Wilcoxon test p-values $>0.18$; Fig. 5). This pattern most probably results from the difficulty in obtaining sufficiently large sample sizes for specimens of the same taxon from the same locality. Although no significant differences are apparent, it is noteworthy that pareiasaurs and titanosuchids have the highest mean oxygen isotope ratios for both horizons, with respectively $6.8 \%$ and $6.7 \%$ for the Karelskraal Member and 6.3\%o both for the Moordenaars Member.

For the Upper Leeuvlei Member, only one specimen of each species was available for sampling, thus precluding any comparison between taxon median oxygen isotope values. The rhinesuchid amphibian has the lowest $\delta{ }^{18} \mathrm{O}$ value and the therocephalian Glanosuchus has the highest, while the dinocephalian Anteosaurus lies in between. 


\subsection{Carbon isotopes}

Similar to the oxygen values, the $\delta^{13} \mathrm{C}_{\mathrm{c}}$ median values are not significantly different from each other (Wilcoxon test p-values $>0.06$ ). This outcome could result from the small sample size, but we note that the highest value documented in the Karelskraal Member corresponds to a titanosuchid, whilst the lowest one corresponds to a specimen of the therocephalian Glanosuchus; the opposite pattern was found for the lower-middle Moordenaars Member (Fig. 6). Pareiasaurs and dinocephalians have a consistent relationship throughout all horizons, with the pareiasaurs having higher median values than all dinocephalians. The Leeuvlei Member is characterized by almost identical values for the rhinesuchid amphibian and Glanosuchus while Anteosaurus is represented by a $\delta^{18} \mathrm{O}$ value $1 \%$ higher.

\section{Discussion}

Among all the sampled taxa, only one rhinesuchid temnospondyl individual represents the aquatic ecology. Indeed, the hypotheses for rhinesuchids being aquatic predators (Schoch and Milner, 2000) has been strongly supported by bone microstructure analysis (McHugh, 2014). Accordingly, a lower stable isotope oxygen value for the rhinesuchid relative to those for all the rest of the terrestrial taxa is expected from this individual (Fig. 5). The value difference between the rhinesuchid and Anteosaurus $(0.79 \pm 0.68 \%)$, or even Glanosuchus $(1.46 \pm 0.92 \%$ ) (Fig. 5; Supplementary Table 1), is lower than those observed between semiaquatic and terrestrial extant mammal species (around 3\%o to 7\%o; Cerling et al., 2008), but within the range observed for extinct reptiles. Indeed, a study on the aquatic ecology of spinosaurids (Amiot et al., 2010) showed differences of less than $2 \%$ between terrestrial theropods and aquatic crocodilians and turtles. 


\subsection{Was Anteosaurus a fully terrestrial therapsid?}

The arguments given by Ivakhnenko (2008, p. 969) in favour of an amphibious lifestyle for Anteosaurus was that it possessed a "high skull with considerably elevated nares and orbits, and thin, gracile skeleton with wide manus and poorly ossified epiphysial regions of tubular bones $[\ldots]$ and the postcranial skeleton corresponds to the aquatic mode of life". The arguments in favour of a terrestrial lifestyle has also made reference to morphology (Kammerer, 2011, pp. 295-296): “Aquatic and semiaquatic piscivores generally have a relatively small cranium (excluding the jaws), as a heavy skull would reduce acceleration during pursuit of evasive prey (Taylor, 1992) [...], the non-jaw region of the skull is massive, extremely so in the giant taxa Titanophoneus and Anteosaurus. The postcranial anatomy of anteosaurids is also not suggestive of amphibious habits. [...] anteosaurids have relatively elongate limbs for dinocephalians (Boonstra, 1955).”

Considerations of taphonomy have tended towards the same conclusion "anteosaur fossils are usually found in deltaic facies (Olson, 1962; Rubidge, 1995), taphonomic evidence suggests that, at least for the South African taxa, these remains were washed in from upland habitats (Boonstra, 1969; Kitching, 1977)." (Kammerer, 2011, p. 296).

In the Karelskraal Member, Anteosaurus has the lowest $\delta^{18} \mathrm{O}_{\mathrm{p}}$ value (Fig. 5), which could indicate that this therapsid had a closer relationship to water than did the other sampled therapsids (Cerling et al., 2008; Amiot et al., 2010). This observation is consistent with the data from the upper Leeuvlei Member, where the $\delta^{18} \mathrm{O}_{\mathrm{p}}$ value obtained for Anteosaurus is intermediate between that of the therapsid Glanosuchus and the rhinesuchid temnospondyl. However, this pattern may be the result of a small sample size because $\delta^{18} \mathrm{O}_{\mathrm{p}}$ values for 
Anteosaurus sampled from the lower-middle Moordenaars Member have a similar range to those measured in other sampled tetrapod taxa from this stratigraphic interval for which larger sample sizes are available $(n \geq 4)$, i.e. pareiasaurs and titanosuchids (Fig. 5). The range of $\delta^{18} \mathrm{O}_{\mathrm{p}}$ values for Anteosaurus also overlaps values obtained for the tapinocephalid Criocephalosaurus $(\mathrm{n}=2)$ and Glanosuchus $(\mathrm{n}=1)$ and even includes the highest recorded value for $\delta^{18} \mathrm{O}(7.5 \%$ ). Therefore, while the value from the Leeuvlei Member belongs to the same range of values from the Moordenaars Member, the very low value from the Karelskraal Member might need more careful consideration as it may not be reflective of the lifestyle of the species.

Distinguishing between a riparian or other terrestrial lifestyles for dinocephalians cannot be tested with stable oxygen isotopes. Extant riparian mammal species, such as the waterbuck Kobus ellipsiprymnus (Pacini and Harper, 2008), show values similar to those of other terrestrial species (Cerling et al., 2008). The "stable isotope tracer" is sensitive to water dependency and not to the habitat of the species. Therefore, based on the few sampled Anteosaurus from the Karoo Basin, our isotopic results tend to favour the terrestrial hypotheses, but cannot determine if the species was riparian or an in-land dweller.

\subsection{Were middle Permian South African pareiasaurs aquatic or terrestrial?}

Previous published suggestions for a semi-aquatic lifestyle in pareiasaurs are even more subjective. "The mode of life of pareiasaurs was similar to that of the hippopotamus: they spent most of the time in water, occasionally coming out" (Khlyupin, 2007, p. 3) or “Ivakhnenko's (2001) believes that details of the skeleton structure of Scutosaurus point to its aquatic mode of life and its poor terrestrial locomotion" (Gubin et al., 2003, p. 522). Kriloff et al. (2008) interpreted Pareiasaurus as an aquatic animal, based on their models from bone 
microanatomy, but changed to semi-aquatic on the basis of morphological characters such as “its morphology (i.e. its well-ossified skeleton, and possibly graviportal adaptations) suggests adequate terrestrial locomotor abilities, and this taxon will be considered as amphibious (rather than aquatic) for the optimizations" (Kriloff et al., 2008, p. 817). Their argument continues further with "The bones of the pareiasaur Bunostegos have been described as spongy and pachyostotic (Sidor et al., 2003, p. 46), which is also compatible with an amphibious or aquatic habitat" (Kriloff et al., 2008, p. 817).

The terrestrial hypothesis is supported by ichnofossils ascribed to pareiasaurs (Gubin et al., 2003; Valentini et al., 2009; Voigt et al., 2010). Other publications support the purported terrestrial lifestyle of pareiasaurs based on limb morphology such as "the numerous postcranial autapomorphies of Bunostegos suggest a suite of derived features related to a relatively parasagittal (i.e., nonsprawling) forelimb posture” (Turner et al., 2015, p. 12). Earlier carbonate stable oxygen isotope analysis also suggests that "pareiasaurs were terrestrial browsers and are inconsistent with the earlier semiaquatic ecomorph hypothesis proposed" (Canoville et al., 2014, p. 7).

Teeth and bones of middle Permian pareiasaurs, which were sampled from both the Moordenaars and the Karelskraal Members of the Abrahamskraal Formation, have similar $\delta^{18} \mathrm{O}_{\mathrm{p}}$ values. The range of these values, approximately $2 \%$, is similar to that of extant mammal species ranging from 2\%o (lion, waterbuck) to 5\%o (rhino, buffalo) (Cerling et al., 2008), a bracket which includes all values obtained for the taxa in our sample. The absence of a significant difference between the median values of the different groups (Wilcoxon test pvalues >0.18; Fig. 5) indicate that dinocephalians, therocephalians, and the pareiasaurs could have shared a similar terrestrial lifestyle. 
This study of the lifestyle of pareiasaurs through a geochemical proxy, the $\delta^{18} \mathrm{O}_{\mathrm{p}}$ values from the phosphate group of the apatite, is in alignment with previously published studies that interpreted pareiasaurs as a fully terrestrial taxon. It is important to stress that this study focused only on middle Permian pareiasaurs from the Karoo Basin of South Africa, which are the oldest pareiasaurs known (Van den Brandt et al., 2019), and that different results might be obtained from analyses of later species.

\section{Conclusions}

Stable oxygen and carbon isotope compositions of phosphate apatite of teeth and bones were analyzed to investigate the debated ecological lifestyle of middle Permian pareiasaurs and the dinocephalian Anteosaurus. Our results demonstrate that the aquatic ecology of the rhinesuchid specimen is strongly supported by its low $\delta^{18} \mathrm{O}_{\mathrm{p}}$ value, the lowest of the horizon. For Anteosaurus, our results favour the terrestrial hypotheses, but a single low $\delta^{18} \mathrm{O}_{\mathrm{p}}$ value questions the robustness of this interpretation. A future isotope study focusing on the ecology of Anteosaurus with an increased sample size may result in a more conclusive outcome. The middle Permian pareiasaurs, on the other hand, are represented by values all indicating a terrestrial way of life, which support the outcomes of previous taphonomic and geochemical studies.

\section{Acknowledgments}

The authors thank the South African Heritage Resources Agency (SAHRA) for their authorization to sample the fossils, and export sub-samples for stable isotope analysis of phosphate (PermitID: 2541). Marion Bamford, Bernhard Zipfel and Sifelani Jirah are 
acknowledged for access to the Karoo fossil collections of the ESI and for sanction to sample the tetrapod fossils. This work was supported by the Palaeontological Scientific Trust (PAST) and its Scatterlings of Africa programmes, National Research Foundation (NRF) African Origins Platform of South Africa (grant no. 98802) and DST/NRF Centre of Excellence in Palaeosciences. 


\section{References}

Amiot, R., Buffetaut, E., Lécuyer, C., Wang, X., Boudad, L., Ding, Z., Fourel, F., Hutt, S., Martineau, F., Medeiros, M.A., Mo, J., Simon, L., Suteethorn, V., Sweetman, S., Tong, H., Zhang, F., Zhou, Z., 2010. Oxygen isotope evidence for semi-aquatic habits among spinosaurid theropods. Geology 38, 139-142. https://doi.org/10.1130/G30402.1

Amiot, R., Lécuyer, C., Buffetaut, E., Fluteau, F., Legendre, S., Martineau, F., 2004. Latitudinal temperature gradient during the Cretaceous Upper Campanian-Middle Maastrichtian: $\delta^{18} \mathrm{O}$ record of continental vertebrates. Earth and Planetary Science Letters 226, 255-272. https://doi.org/10.1016/j.eps1.2004.07.015

Amiot, R., Lécuyer, C., Escarguel, G., Billon-Bruyat, J.-P., Buffetaut, E., Langlois, C., Martin, S., Martineau, F., Mazin, J.-M., 2007. Oxygen isotope fractionation between crocodilian phosphate and water. Palaeogeography, Palaeoclimatology, Palaeoecology 243, 412-420. https://doi.org/10.1016/j.palaeo.2006.08.013

Benton, M.J., Newell, A.J., Khlyupin, A.Yu., Shumov, I.S., Price, G.D., Kurkin, A.A., 2012. Preservation of exceptional vertebrate assemblages in Middle Permian fluviolacustrine mudstones of Kotel'nich, Russia: stratigraphy, sedimentology, and taphonomy. Palaeogeography, Palaeoclimatology, Palaeoecology 319-320, 58-83. https://doi.org/10.1016/j.palaeo.2012.01.005

Bocherens, H., Koch, P.L., Mariotti, A., Geraads, D., Jaeger, J.-J., 1996. Isotopic biogeochemistry $\left(\delta^{13} \mathrm{C}, \delta^{18} \mathrm{O}\right)$ of mammalian enamel from African Pleistocene hominid sites. Palaios 306-318.

Boitsova, E.A., Skutschas, P.P., Sennikov, A.G., Golubev, V.K., Masuytin, V.V., Masuytina, O.A., 2019. Bone histology of two pareiasaurs from Russia (Deltavjatia rossica and 
Scutosaurus karpinskii) with implications for pareiasaurian palaeobiology. Biol J Linn Soc 1-22. https://doi.org/10.1093/biolinnean/blz094

Bond, D.P.G., Wignall, P.B., 2014. Large igneous provinces and mass extinctions: an update. Geological Society of America Special Papers 505, SPE505-02.

Bond, D.P.G., Wignall, P.B., Wang, W., Izon, G., Jiang, H., Lai, X., Sun, Y., Newton, R.J., Shao, L.-Y., Védrine, S., others, 2010. The mid-Capitanian (Middle Permian) mass extinction and carbon isotope record of South China. Palaeogeography, Palaeoclimatology, Palaeoecology 292, 282-294.

Boonstra, L.D., 1969. The fauna of the Tapinocephalus zone (Beaufort beds of the Karoo). Annals of The South African Museum 56, 1-73.

Boonstra, L.D., 1962. The dentition of the titanosuchian dinocephalians. Annals of The South African Museum 46, 57-112.

Boonstra, L.D., 1955. The girdles and limbs of the South African Deinocephalia. Annals of The South African Museum 42, 185-326.

Bryant, J.D., Froelich, P.N., 1995. A model of oxygen isotope fractionation in body water of large mammals. Geochimica et Cosmochimica Acta 59, 4523-4537. https://doi.org/10.1016/0016-7037(95)00250-4

Canoville, A., Chinsamy, A., 2017. Bone Microstructure of Pareiasaurs (Parareptilia) from the Karoo Basin, South Africa: Implications for Growth Strategies and Lifestyle Habits. The Anatomical Record 300, 1039-1066.

Canoville, A., Chinsamy, A., 2015. Bone microstructure of the stereospondyl Lydekkerina huxleyi reveals adaptive strategies to the harsh post Permian-extinction environment. The Anatomical Record 298, 1237-1254. https://doi.org/10.1002/ar.23160 
Canoville, A., Laurin, M., 2010. Evolution of humeral microanatomy and lifestyle in amniotes, and some comments on palaeobiological inferences. Biological Journal of the Linnean Society 100, 384-406. https://doi.org/10.1111/j.1095-8312.2010.01431.x

Canoville, A., Thomas, D.B., Chinsamy, A., 2014. Insights into the habitat of Middle Permian pareiasaurs (Parareptilia) from preliminary isotopic analyses. Lethaia 47, 266-274.

Case, E.C., 1926. Environment of tetrapod life in the late Paleozoic of regions other than North America. Carnegie institution of Washington.

Cerling, T.E., Harris, J.M., Hart, J.A., Kaleme, P., Klingel, H., Leakey, M.G., Levin, N.E., Lewison, R.L., Passey, B.H., 2008. Stable isotope ecology of the common hippopotamus. Journal of Zoology 276, 204-212. https://doi.org/10.1111/j.14697998.2008.00450.x

Cisneros, J.C., Abdala, F., Atayman-Güven, S., Rubidge, B.S., Şengör, A.M.C., Schultz, C.L., 2012. Carnivorous dinocephalian from the Middle Permian of Brazil and tetrapod dispersal in Pangaea. PNAS 109, 1584-1588.

https://doi.org/10.1073/pnas.1115975109

Clementz, M.T., Holroyd, P.A., Koch, P.L., 2008. Identifying Aquatic Habits Of Herbivorous Mammals Through Stable Isotope Analysis. PALAIOS 23, 574-585. https://doi.org/10.2110/palo.2007.p07-054r

Coplen, T.B., Kendall, C., Hopple, J., 1983. Comparison of stable isotope reference samples. Nature 302, 236.

D’Angela, D., Longinelli, A., 1990. Oxygen isotopes in living mammal's bone phosphate: Further results. Chemical Geology: Isotope Geoscience section 86, 75-82. https://doi.org/10.1016/0168-9622(90)90007-Y 
Day, M., Benson, R.B.J., Kammerer, C.F., Rubidge, B., 2018. Evolutionary rates of midPermian tetrapods from South Africa and the role of temporal resolution in turnover reconstruction. Paleobiology.

Day, M.O., Ramezani, J., Bowring, S.A., Sadler, P.M., Erwin, D.H., Abdala, F., Rubidge, B.S., 2015. When and how did the terrestrial mid-Permian mass extinction occur? Evidence from the tetrapod record of the Karoo Basin, South Africa. Proceedings of the Royal Society of London B: Biological Sciences 282, 20150834.

Fröbisch, J., 2009. Composition and similarity of global anomodont-bearing tetrapod faunas. Earth-Science Reviews 95, 119-157.

Golubev, V.K., 2015. Dinocephalian stage in the history of the Permian tetrapod fauna of Eastern Europe. Paleontological Journal 49, 1346-1352.

Golubev, V.K., 2005. Permian tetrapod stratigraphy. New Mexico Museum of Natural History and Science Bulletin 30, 95-99.

Gubin, Y.M., Golubev, V.K., Bulanov, V.V., Petuchov, S.V., 2003. Pareiasaurian tracks from the upper Permian of Eastern Europe. PALEONTOLOGICAL JOURNAL C/C OF PALEONTOLOGICHESKII ZHURNAL 37, 514-523.

Hallam, A., Wignall, P.B., 1999. Mass extinctions and sea-level changes. Earth-Science Reviews 48, 217-250. https://doi.org/10.1016/S0012-8252(99)00055-0

Hut, G., 1987. Consultants' group meeting on stable isotope reference samples for geochemical and hydrological investigations.

Iacumin, P., Bocherens, H., Mariotti, A., Longinelli, A., 1996. Oxygen isotope analyses of coexisting carbonate and phosphate in biogenic apatite: a way to monitor diagenetic alteration of bone phosphate? Earth and Planetary Science Letters 142, 1-6. https://doi.org/10.1016/0012-821X(96)00093-3 
Isozaki, Y., Yao, J., Ji, Z., Saitoh, M., Kobayashi, N., Sakai, H., 2008. Rapid sea-level change in the Late Guadalupian (Permian) on the Tethyan side of South China: litho-and biostratigraphy of the Chaotian section in Sichuan. Proceedings of the Japan Academy. Series B, Physical and biological sciences 84, 344 .

Ivakhnenko, M.F., 2008. Cranial morphology and evolution of Permian Dinomorpha (Eotherapsida) of eastern Europe. Paleontol. J. 42, 859-995. https://doi.org/10.1134/S0031030108090013

Ivakhnenko, M.F., 2001. Tetrapods from the east european placket-Late Paleozoic natural territorial complex. Tr. Paleontol. Inst. Ross. Akad. Nauk 283, 1-200.

Jasinoski, S.C., Rayfield, E.J., Chinsamy, A., 2009. Comparative feeding biomechanics of Lystrosaurus and the generalized dicynodont Oudenodon. The Anatomical Record: Advances in Integrative Anatomy and Evolutionary Biology: Advances in Integrative Anatomy and Evolutionary Biology 292, 862-874.

Jin, Y.G., Zhang, J., Shang, Q.H., 1994. Two phases of the end-Permian mass extinction, in: Embry, A.F., Beauchamp, B., Glass, D.J. (Eds.), Pangea: Global Environments and Resources. Memoir, pp. 818-822.

Kammerer, C.F., 2011. Systematics of the Anteosauria (Therapsida: Dinocephalia). Journal of Systematic Palaeontology 9, 261-304. https://doi.org/10.1080/14772019.2010.492645

Kemp, T.S., 2012. The origin and radiation of Therapsids, in: Chinsamy-Turan, A. (Ed.), Forerunners of Mammals: Radiation, Histology, Biology. Indiana University Press, Bloomington, pp. 3-28.

Khlyupin, A.Y., 2007. Cemetery of the Permian reptiles. Paleomir 1, 50-57.

Kitching, J.W., 1977. The distribution of the Karroo vertebrate fauna: with special reference to certain genera and the bearing of this distribution on the zoning of the Beaufort 
beds. Bernard Price Institute for Palaeontological Research, University of the Witwatersrand.

Koch, P.L., Tuross, N., Fogel, M.L., 1997. The effects of sample treatment and diagenesis on the isotopic integrity of carbonate in biogenic hydroxylapatite. Journal of Archaeological Science 24, 417-430.

Kohn, M.J., 1996. Predicting animal $\delta^{18} \mathrm{O}$ : Accounting for diet and physiological adaptation. Geochimica et Cosmochimica Acta 60, 4811-4829. https://doi.org/10.1016/S00167037(96)00240-2

Kohn, M.J., Schoeninger, M., Valley, J., 1996. Herbivore tooth oxygen isotope compositions: Effects of diet and physiology. Geochimica and Cosmochimica Acta 60, 3889-3896. https://doi.org/10.1016/0016-7037(96)00248-7

Kriloff, A., Germain, D., Canoville, A., Vincent, P., Sache, M., Laurin, M., 2008. Evolution of bone microanatomy of the tetrapod tibia and its use in palaeobiological inference. Journal of Evolutionary Biology 21, 807-826. https://doi.org/10.1111/j.14209101.2008.01512.x

Krull, E.S., Retallack, G.J., 2000. $\delta^{13} \mathrm{C}$ depth profiles from paleosols across the PermianTriassic boundary: Evidence for methane release. Geological Society of America Bulletin 112, 1459-1472. https://doi.org/10.1130/00167606(2000)112<1459:CDPFPA>2.0.CO;2

Krull, E.S., Retallack, G.J., Campbell, H.J., Lyon, G.L., 2000. $\delta^{13} \mathrm{C}_{\mathrm{org}}$ chemostratigraphy of the Permian-Triassic boundary in the Maitai Group, New Zealand: Evidence for highlatitudinal methane release. New Zealand Journal of Geology and Geophysics 43, 2132.

Kurkin, A.A., 2011. Permian anomodonts: paleobiogeography and distribution of the group. Paleontological Journal 45, 432. 
Lécuyer, C., 2004. Oxygen isotope analysis of phosphate. Handbook of stable isotope analytical techniques $1,482-499$.

Lécuyer, C., Balter, V., Martineau, F., Fourel, F., Bernard, A., Amiot, R., Gardien, V., Otero, O., Legendre, S., Panczer, G., Simon, L., Martini, R., 2010. Oxygen isotope fractionation between apatite-bound carbonate and water determined from controlled experiments with synthetic apatites precipitated at $10-37^{\circ} \mathrm{C}$. Geochimica et Cosmochimica Acta 74, 2072-2081. https://doi.org/10.1016/j.gca.2009.12.024

Lécuyer, C., Grandjean, P., O’Neil, J.R., Cappetta, H., Martineau, F., 1993. Thermal excursions in the ocean at the Cretaceous-Tertiary boundary (northern Morocco): $\delta^{18} \mathrm{O}$ record of phosphatic fish debris. Palaeogeography, Palaeoclimatology, Palaeoecology $105,235-243$.

Lécuyer, C., Grandjean, P., Sheppard, S.M.F., 1999. Oxygen isotope exchange between dissolved phosphate and water at temperatures $\leq 135^{\circ} \mathrm{C}$ : inorganic versus biological fractionations. Geochimica and Cosmochimica Acta 63, 855-862. https://doi.org/10.1016/S0016-7037(99)00096-4

Lee, M.S.Y., 1997. A taxonomic revision of pareiasaurian reptiles: implications for Permian terrestrial palaeoecology. Modern Geology 21, 231-298. https://doi.org/10.1111/j.1096-3642.1997.tb01279.x

Liu, J., 2013. Osteology, ontogeny, and phylogenetic position of Sinophoneus yumenensis (Therapsida, Dinocephalia) from the Middle Permian Dashankou Fauna of China. Journal of Vertebrate Paleontology 33, 1394-1407.

Luz, B., Kolodny, Y., 1985. Oxygen isotope variations in phosphate of biogenic apatites, IV. Mammal teeth and bones. Earth and Planetary Science Letters 75, 29-36. https://doi.org/10.1016/0012-821X(85)90047-0 
McHugh, J.B., 2014. Paleohistology and histovariability of the Permian stereospondyl Rhinesuchus. Journal of Vertebrate Paleontology 34, 59-68. https://doi.org/10.1080/02724634.2013.787429

Mills, A., 1967. Structural and Chemical Organization of Teeth. Elsevier.

Nicolas, M., Rubidge, B.S., 2010. Changes in Permo-Triassic terrestrial tetrapod ecological representation in the Beaufort Group (Karoo Supergroup) of South Africa. Lethaia 43, 45-59. https://doi.org/10.1111/j.1502-3931.2009.00171.x

Ochev, V.G., 2004. Materials to the tetrapod history at the Paleozoic-Mesozoic boundary, in: Sixth Symposium on Mesozoic Terrestrial Ecosystems and Biota, Short Papers. Beijing: China Ocean Press. p. pp. 43-46.

Olson, E.C., 1962. Late Permian terrestrial vertebrates, USA and USSR. Transactions of the American Philosophical Society 52, 1-224.

Pacini, N., Harper, D.M., 2008. 6 - Aquatic, Semi-Aquatic and Riparian Vertebrates, in: Dudgeon, D. (Ed.), Tropical Stream Ecology, Aquatic Ecology. Academic Press, London, pp. 147-197. https://doi.org/10.1016/B978-012088449-0.50008-X

Retallack, G.J., Jahren, A.H., 2008. Methane release from igneous intrusion of coal during Late Permian extinction events. The Journal of Geology 116, 1-20. https://doi.org/10.1086/524120

Rey, K., Amiot, R., Fourel, F., Abdala, F., Fluteau, F., Jalil, N.-E., Liu, J., Rubidge, B.S., Smith, R.M., Steyer, J.S., Viglietti, P.A., Wang, X., Lécuyer, C., 2017. Oxygen isotopes suggest elevated thermometabolism within multiple Permo-Triassic therapsid clades. eLife 6, e28589. https://doi.org/10.7554/eLife.28589

Rey, K., Amiot, R., Fourel, F., Rigaudier, T., Abdala, F., Day, M.O., Fernandez, V., Fluteau, F., France-Lanord, C., Rubidge, B.S., Smith, R.M., Viglietti, P.A., Zipfel, B., Lécuyer, C., 2016. Global climate perturbations during the Permo-Triassic mass extinctions 
recorded by continental tetrapods from South Africa. Gondwana Research 37, 384396. https://doi.org/10.1016/j.gr.2015.09.008

Rey, K., Day, M.O., Amiot, R., Goedert, J., Lécuyer, C., Sealy, J., Rubidge, B.S., 2018. Stable isotope record implicates aridification without warming during the late Capitanian mass extinction. Gondwana Research 59, 1-8.

Rubidge, B.S., 1995. Biostratigraphy of the Beaufort Group (Karoo Supergroup), Biostratigraphic Series. Geological Survey, Pretoria.

Saitoh, M., Isozaki, Y., Yao, J., Ji, Z., Ueno, Y., Yoshida, N., 2013. The appearance of an oxygen-depleted condition on the Capitanian disphotic slope/basin in South China: Middle-Upper Permian stratigraphy at Chaotian in northern Sichuan. Global and Planetary Change 105, 180-192. https://doi.org/10.1016/j.gloplacha.2012.01.002

Schoch, R.R., Milner, A.R., 2000. Handbuch der Palaoherpetologie: 3B Stereospondyli. Munich: Verlag Dr. Friedrich Pfeil.

Sheldon, N.D., Chakrabarti, R., Retallack, G.J., Smith, R.M., 2014. Contrasting geochemical signatures on land from the Middle and Late Permian extinction events. Sedimentology 61, 1812-1829.

Sidor, C.A., Blackburn, D.C., Gado, B., 2003. The vertebrate fauna of the Upper Permian of Niger-II, Preliminary description of a new pareiasaur.

Svensen, H., Planke, S., Polozov, A.G., Schmidbauer, N., Corfu, F., Podladchikov, Y.Y., Jamtveit, B., 2009. Siberian gas venting and the end-Permian environmental crisis. Earth and Planetary Science Letters 277, 490-500. https://doi.org/10.1016/j.epsl.2008.11.015

Taylor, 1992. Functional anatomy of the head of the large aquatic predator Rhomaleosaurus zetlandicus (Plesiosauria, Reptilia) from the Toarcian (Lower Jurassic) of Yorkshire, 
England. Philosophical Transactions of the Royal Society of London. Series B:

Biological Sciences 335, 247-280. https://doi.org/10.1098/rstb.1992.0022

Tudge, A.P., 1960. A method of analysis of oxygen isotopes in orthophosphate-its use in the measurement of paleotemperatures. Geochimica et Cosmochimica Acta 18, 81-93. https://doi.org/10.1016/0016-7037(60)90019-3

Turner, M.L., Tsuji, L.A., Ide, O., Sidor, C.A., 2015. The vertebrate fauna of the upper Permian of Niger-IX. The appendicular skeleton of Bunostegos akokanensis (Parareptilia: Pareiasauria). Journal of Vertebrate Paleontology 35, e994746.

Valentini, M., Nicosia, U., Conti, M.A., 2009. A re-evaluation of Pachypes, a pareiasaurian track from the Late Permian. Neues Jahrbuch für Geologie und PaläontologieAbhandlungen 251, 71-94.

Van den Brandt, M.J., Abdala, F., Rubidge, B.S., 2019. Cranial morphology and phylogenetic relationships of the Middle Permian pareiasaur Embrithosaurus schwarzi from the Karoo Basin of South Africa. Zoological Journal of the Linnean Society 1-40.

Verrière, A., Brocklehurst, N., Fröbisch, J., 2016. Assessing the completeness of the fossil record: comparison of different methods applied to parareptilian tetrapods (Vertebrata: Sauropsida). Paleobiology 42, 680-695.

Voigt, S., Hminna, A., Saber, H., Schneider, J.W., Klein, H., 2010. Tetrapod footprints from the uppermost level of the Permian Ikakern Formation (Argana Basin, Western High Atlas, Morocco). Journal of African Earth Sciences 57, 470-478. https://doi.org/10.1016/j.jafrearsci.2009.12.003

Wignall, P.B., Sun, Y., Bond, D.P.G., Izon, G., Newton, R.J., Védrine, S., Widdowson, M., Ali, J.R., Lai, X., Jiang, H., Cope, H., Bottrell, S.H., 2009. Volcanism, mass extinction, and carbon isotope fluctuations in the Middle Permian of China. Science 324, 1179-1182. https://doi.org/10.1126/science.1171956 
Zazzo, A., Lécuyer, C., Mariotti, A., 2004. Experimentally-controlled carbon and oxygen isotope exchange between bioapatites and water under inorganic and microbiallymediated conditions. Geochimica et Cosmochimica Acta 68, 1-12. https://doi.org/10.1016/S0016-7037(03)00278-3

Zhou, M.-F., Malpas, J., Song, X.-Y., Robinson, P.T., Sun, M., Kennedy, A.K., Lesher, C.M., Keays, R.R., 2002. A temporal link between the Emeishan large igneous province (SW China) and the end-Guadalupian mass extinction. Earth and Planetary Science Letters 196, 113-122. https://doi.org/10.1016/S0012-821X(01)00608-2

\section{Figure captions}

Figure 1: Mean oxygen isotope compositions of apatites versus drinking waters of mammals from two Kenyan parks (Bocherens et al., 1996; Cerling et al., 2008) showing difference in $\delta^{18} \mathrm{O}_{\mathrm{p}}$ values between semiaquatic hippopotamuses and terrestrial herbivorous mammals (error bars are $\pm 1 \sigma$ ). V-SMOW-Vienna standard mean ocean water. Phosphate-water fractionation lines of terrestrial placental mammals, freshwater turtles, and crocodilians are displayed for comparison. Equations from Coplen et al., (1983) and Lécuyer et al., (2010) were used to respectively convert $\delta^{18} \mathrm{O}_{\mathrm{c}}$ (V-PDB) values from Cerling et al. (2008) into $\delta^{18} \mathrm{O}_{\mathrm{c}}$ (V-SMOW) values and $\delta^{18} \mathrm{O}_{c}(\mathrm{~V}-\mathrm{SMOW})$ values from Bocherens et al. (1996) and Cerling et al. (2008) to $\delta^{18} \mathrm{O}_{\mathrm{p}}$ (V-SMOW) values. Updated from Amiot et al., (2010).

Figure 2: Studied localities along with the main lithostratigraphic units of the western part of the Main Karoo Basin bordering the Cape Fold Belt. Farm name abbreviations are B: 
Buffelsvlei; DB: De Bad; DD: Die Drift; R: Rietfontein; SMK: Schoppel Maay Kraal; Sp: Spinnekopkraal; St: Stinkfontein; W: Wolwehoek.

Figure 3: Phosphate $\delta^{18} \mathrm{O}_{\mathrm{p}}$ values plotted against corresponding carbonate $\delta^{18} \mathrm{O}_{\mathrm{c}}$ values, together with the empirical isotopic equilibrium line (Iacumin et al., 1996) with a slope close to unity (bold line). The altered samples are within the circle. The reduced major axis regression lines are represented for all samples (dash line) except unaltered ones (full line).

Figure 4: Bone values $\left({ }_{b}\right)$ are plotted against tooth values $\left(_{t}\right)$ of the same individual and compared to a line with a slope of 1 , for their $\delta^{18} \mathrm{O}_{\mathrm{p}}$ values $(\mathrm{A}), \delta^{18} \mathrm{O}_{\mathrm{c}}$ values $(\mathrm{B})$ and $\delta^{13} \mathrm{C}_{\mathrm{c}}$ values (C). V-PDB: Vienna PeeDee Belemnite; V-SMOW: Vienna standard mean ocean water.The circled $\delta^{18} \mathrm{O}_{\mathrm{c}}$ value corresponds to the sample 1782-B considered as altered (see text).

Figure 5: Box plot of apatite $\delta^{18} \mathrm{O}_{\mathrm{p}}$ values of each taxon plotted within their respective stratigraphic Member. V-SMOW: Vienna standard mean ocean water. A: Anteosaurus; C: Criocephalosaurus; G: Glanosuchus; P: Pareiasauridae; R: Rhinesuchidae; Ta: Tapinocephalidae; Ti: Titanosuchidae.

Figure 6: Box plot of apatite $\delta^{13} \mathrm{C}_{\mathrm{c}}$ values of each taxon plotted within their respective stratigraphic Member. V-PDB: Vienna PeeDee Belemnite. A: Anteosaurus; C: Criocephalosaurus; G: Glanosuchus; P: Pareiasauridae; R: Rhinesuchidae; Ti: Titanosuchidae. 
Table 1: Mean oxygen isotope compositions of apatites of mammals from two Kenyan parks (Bocherens et al., 1996; Cerling et al., 2008). V-PDB: Vienna PeeDee Belemnite; V-SMOW: Vienna standard mean ocean water. Equations from Coplen et al., (1983) and Lécuyer et al., (2010) were used to respectively convert $\delta^{18} \mathrm{O}_{c}(\mathrm{~V}-\mathrm{PDB})$ values into $\delta^{18} \mathrm{O}_{\mathrm{c}}(\mathrm{V}-\mathrm{SMOW})$ values and $\delta^{18} \mathrm{O}_{\mathrm{c}}(\mathrm{V}-\mathrm{SMOW})$ values into $\delta^{18} \mathrm{O}_{\mathrm{p}}(\mathrm{V}-\mathrm{SMOW})$ values. SD correspond to $\pm 1 \sigma$. 


\section{Declaration of interests}

$\bigotimes$ The authors declare that they have no known competing financial interests or personal relationships that could have appeared to influence the work reported in this paper.

$\square$ The authors declare the following financial interests/personal relationships which may be considered as potential competing interests: 
Table 1.

\begin{tabular}{|c|c|c|c|c|c|c|c|c|}
\hline \multicolumn{9}{|c|}{ Mean oxygen isotope compositions of apatites of mammals from two Kenyan parks } \\
\hline \multirow[t]{3}{*}{ Common name } & \multirow[t]{3}{*}{ Species name } & \multicolumn{3}{|c|}{ Tsavo National Park } & \multicolumn{4}{|c|}{ Ambolesi Park } \\
\hline & & $\delta^{18} \mathrm{O}_{\mathrm{c}}$ & $\delta^{18} \mathrm{O}_{\mathrm{p}}$ & SD & $\delta^{18} \mathrm{O}_{c}$ & $\delta^{18} \mathrm{O}_{\mathrm{c}}$ & $\delta^{18} \mathrm{O}_{\mathrm{p}}$ & SD \\
\hline & & \multicolumn{2}{|c|}{$\begin{array}{r}(\%, \mathrm{~V}- \\
\text { SMOW) }\end{array}$} & & $(\%, \mathrm{~V}-\mathrm{PDB})$ & \multicolumn{2}{|c|}{$\begin{array}{r}(\%, \mathrm{~V}- \\
\text { SMOW) }\end{array}$} & \\
\hline \multicolumn{9}{|c|}{ Terrestrial species } \\
\hline Buffalo & Syncerus caffer & 30.9 & 21.8 & 1.4 & 1.7 & 32.7 & 23.5 & 0.9 \\
\hline Elephant & Loxodonta africana & 29.8 & 20.7 & 0.9 & 0.5 & 31.4 & 22.3 & 0.6 \\
\hline Giraffe & Giraffa camelopardalis & & & & 4.3 & 35.3 & 26.1 & 0.8 \\
\hline Lion & Panthera leo & & & & Ser & 31.6 & 22.5 & 0.5 \\
\hline Oryx & Oryx beisa & & se & 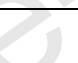 & 2.4 & 33.4 & 24.2 & 1.7 \\
\hline Rhinoceros & Diceros bicornis & 29.5 & 20.4 & 1.3 & 0.7 & 31.6 & 22.5 & 1.4 \\
\hline Warthog & Phacochoerus aethiopicus & 31.0 & 21.9 & - & & & & \\
\hline Waterbuck & Kobus ellipsiprymnus & & & & 2.4 & 33.4 & 24.2 & 0.9 \\
\hline Wildebeest & Connochaetes taurinus & 33.4 & 24.2 & 0.9 & & & & \\
\hline Zebra & Equus burchelli & 31.4 & 22.3 & 1.5 & 3.2 & 34.2 & 25.0 & 1.6 \\
\hline \multicolumn{9}{|c|}{ Semi-aquatic species } \\
\hline Hippopotamus & Hippopotamus amphibius & 26.9 & 17.9 & 1.6 & -2.7 & 28.1 & 19.1 & 0.8 \\
\hline
\end{tabular}

V-PDB: Vienna PeeDee Belemnite.

V-SMOW: Vienna standard mean ocean water.

Equations from Coplen et al., (1983) was used to convert $\delta 18 \mathrm{Oc}$ (V-PDB) values into $\delta 18 \mathrm{Oc}$ (V-SMOW) values.

Equations from Lécuyer et al., (2010) was used to convert $\delta 18 \mathrm{Oc}(\mathrm{V}-\mathrm{SMOW})$ values into $\delta 18 \mathrm{Op}$ (V-SMOW) values.

$\mathrm{SD}$ correspond to $\pm 1 \sigma$. 


\section{Highlights:}

- First application of $\delta^{18} \mathrm{O}_{\mathrm{p}}$ of apatite to South African tetrapods for paleoecology.

- The lifestyle of middle Permian pareiasaurs is strongly shown to be terrestrial.

- The carnivorous dinocephalian Anteosaurus was probably living a terrestrial ecology.

- Knowing the ecology of major species helps understand the nature of the extinction. 


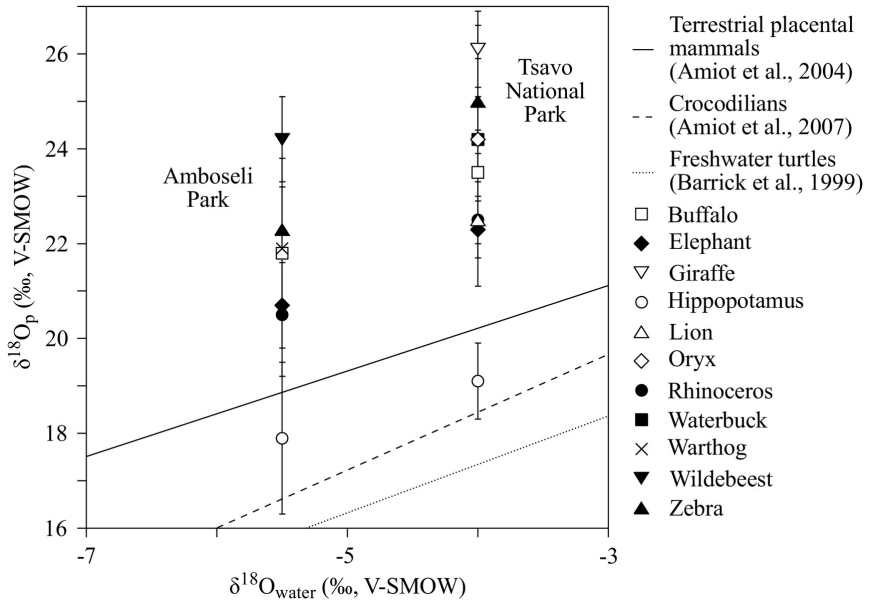

Figure 1 


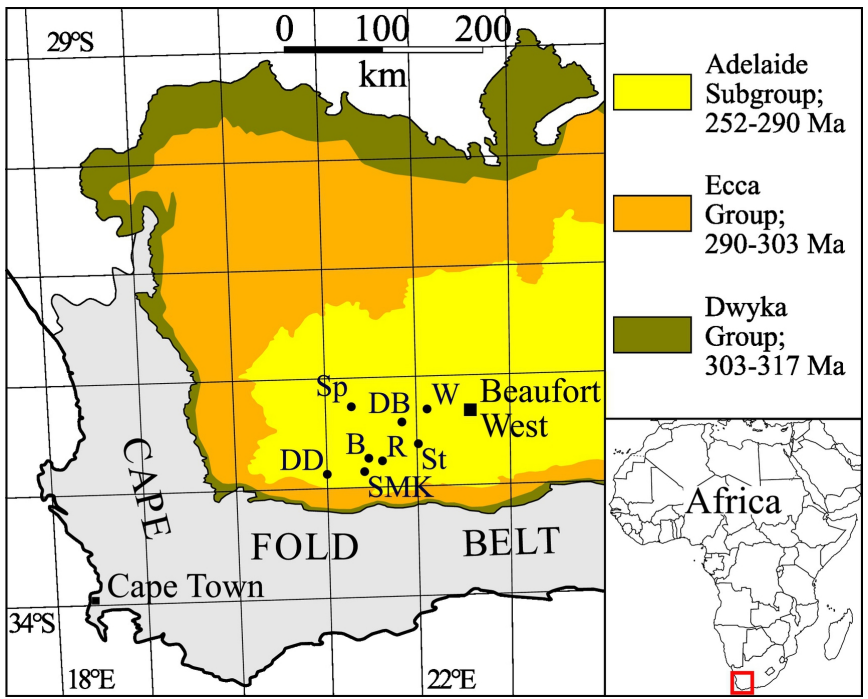

Figure 2 


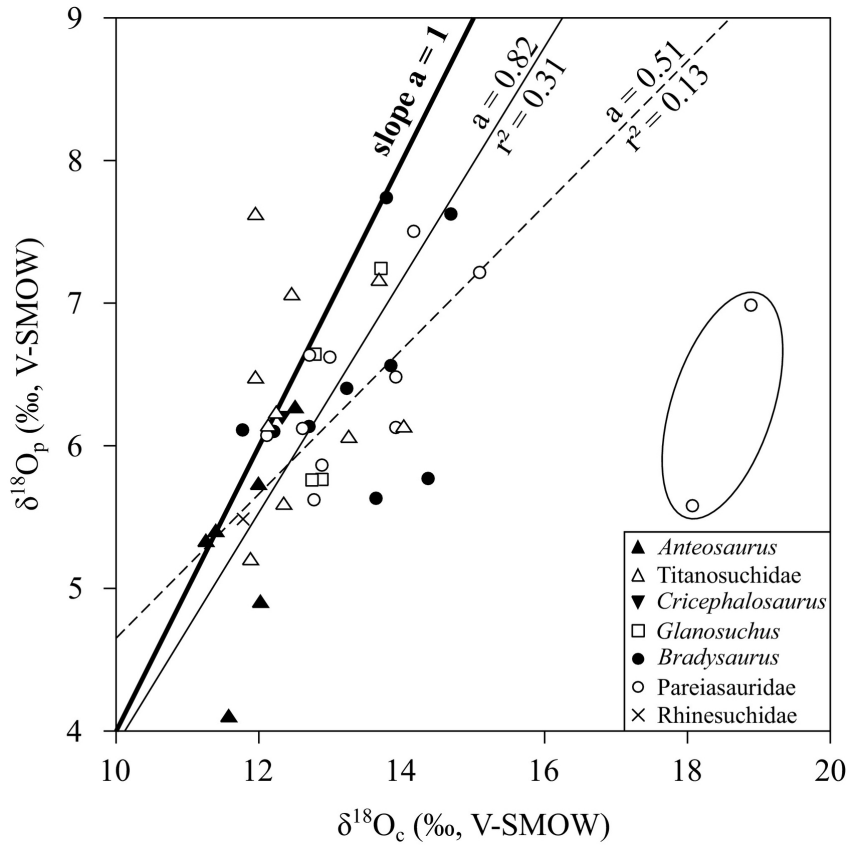

Figure 3 

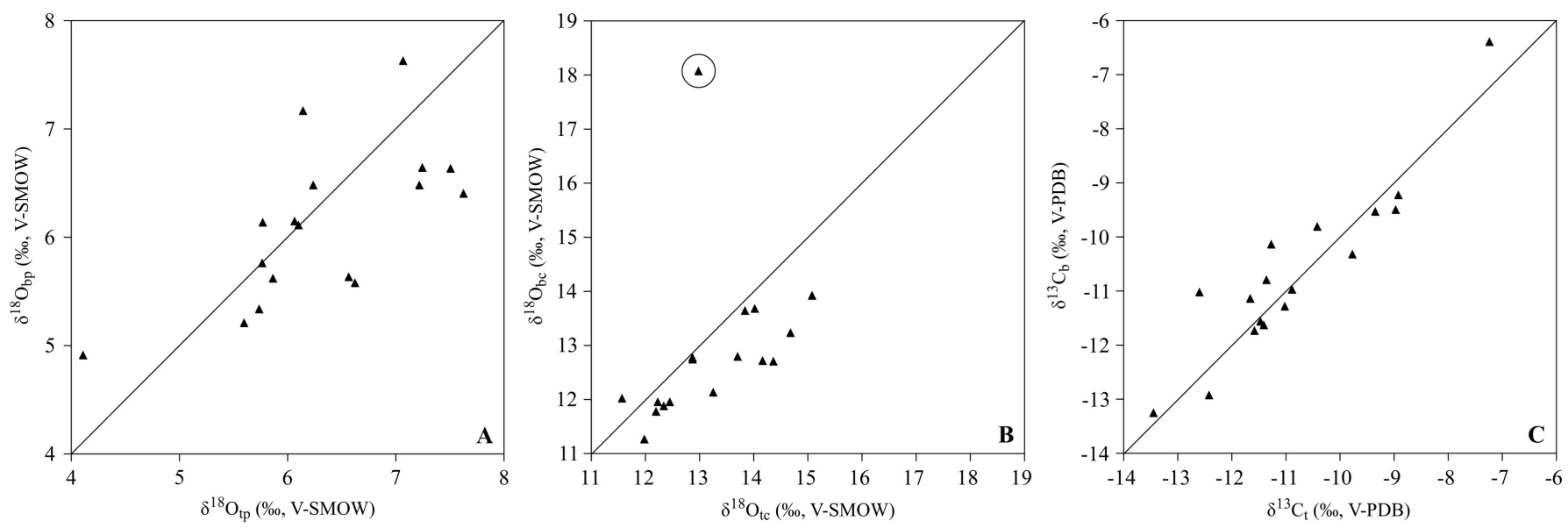

Figure 4 


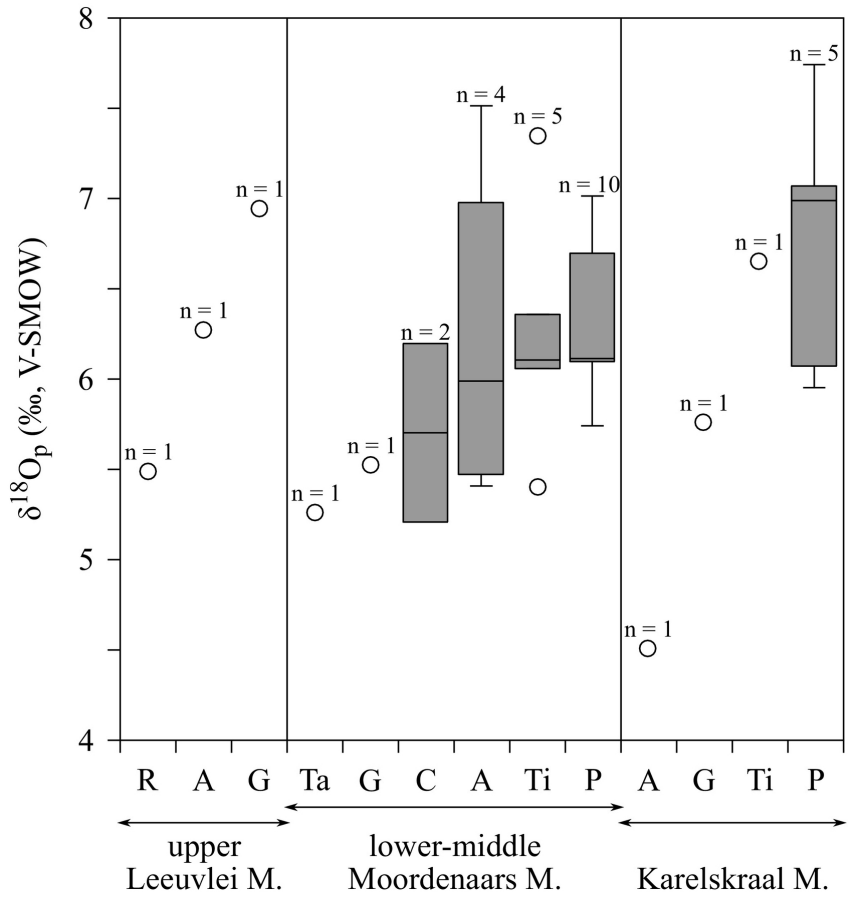

Figure 5 


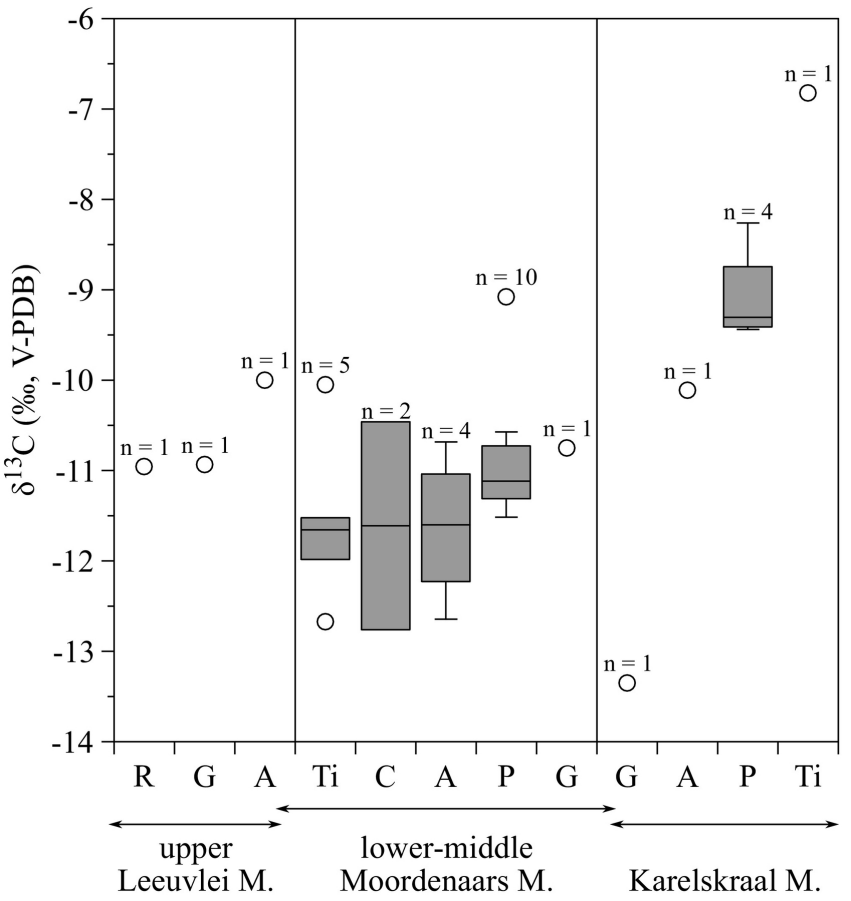

Figure 6 